\title{
Red, White and Black: Colors of Beauty, Tints of Health and Cosmetic Materials in Early Modern English Art Writing
}

\author{
Romana Sammern \\ University of Salzburg \\ romana.sammern@sbg.ac.at
}

\begin{abstract}
Alongside Richard Haydocke's translation of Giovanni Paolo Lomazzo's treatise on painting (1598), the article examines concepts of color concerning cosmetics, painting and complexion as they relate to aesthetics, artistic and medical practice in the sixteenth and seventeenth centuries. Beginning with white and red as ideal colors of beauty in Agnolo Firenzuola's Discourse on the beauty of women (1541), the essay places color in relation to major issues in art, medicine and empiricism by discussing beauty as a quality of humoral theory and its colors as visual results of physiological processes. Challenging the relation of art and nature, gender and production, Lomazzo's account of complexion and Haydocke's additions on cosmetic practices and face-painting provide key passages that shed light on the relation of cosmetics colors, art writing and artistic practices at the convergence of the body, art and medicine in the context of the emerging English virtuosi around 1600.
\end{abstract}

* University of Salzburg, Department of Art History, Erzabt-Klotz-Straße 1, Salzburg 5020, Austria. This paper presents considerations about a research project on painting and facepainting in the early modern period that is funded by the Austrian Science Fund at the University of Salzburg. The author would like to thank Henrike Eibelshäuser, Roman Fuchs, Laura Gronius, Hayley Haupt, Wolf-Dietrich Löhr, Philipp Sammern, and Julia Saviello as well as the participants of the Early Modern Color Worlds Working Group, especially Sven Dupré, Karin Leonhard and Doris Oltrogge, for their comments, discussions and critical support. Translations, unless otherwise indicated, are by the author. 


\section{Keywords}

aesthetics - art theory - beauty - art writing - color - colorants - cosmetics - medicine - pharmacology - virtuoso - Giovanni Paolo Lomazzo - Richard Haydocke Nicholas Hilliard - Agnolo Firenzuola

\section{Introduction}

This article examines the canonical colors of beauty in the early modern period - red, white and black - at the convergence of cosmetics, medicine, art theory and painting practices. Following Agnolo Firenzuola's (1493-1543) link between the colors of beauty, physiology and the colors of health as well as Richard Haydocke's (ca. 1569/70-1642) connection between cosmetics and painting, it discusses concepts of the colors of beauty, coloring materials as well as material knowledge. Together with William Harvey (1578-1657) and Sir Théodore Turquet de Mayerne (1573-1655), Haydocke belonged to a generation of English physicians that shared a common interest and engagement in medicine, empiricism and art. ${ }^{1}$ Alongside his Tracte of paintinge (1598), it will discuss recipe sources and cosmetic ingredients within the framework of art writing, focusing on the question of the meaning of the colors of beauty around 1600 .

\section{The Early Modern Canon of Beauty}

The ideal Renaissance face was a composition of white and red: a high forehead free from hair and wrinkles, and skin, even and whitened, accentuated by a blush on the cheeks and the red of the lips. ${ }^{2}$ The portrait of Lady Mary

1 Craig A. Hanson, The English Virtuoso: Art, Medicine, and Antiquarianism in the Age of Empiricism (Chicago, 2008), 21-57.

2 On the colors of female beauty and cosmetics, see Fenja Gunn, The Artificial Face: A History of Cosmetics (New York, 1973); Giuliana Grando, Profumi e cosmesi nella Venezia del '5oo (Venice, 1985); Jacqueline Lichtenstein, "Making Up Representation: The Risks of Feminity," Representations, 20 (1987), 77-87; Mariacarla Gadebusch Bondio, Medizinische Ästhetik: Kosmetik und plastische Chirurgie zwischen Antike und früher Neuzeit (Munich, 2005); Farah Karim-Cooper, Cosmetics in Shakespearean and Renaissance Drama (Edinburgh, 2006); Patricia Phillippy, Painting Women: Cosmetics, Canvases, and Early Modern Culture (Baltimore, 2006); Catherine Lanoë, La poudre et le fard: Une histoire des cosmétiques de la Renaissance aux lumières (Seyssel, 2008); Le bain et le miroir: Soins du corps et cosmétiques de l'Antiquité à 


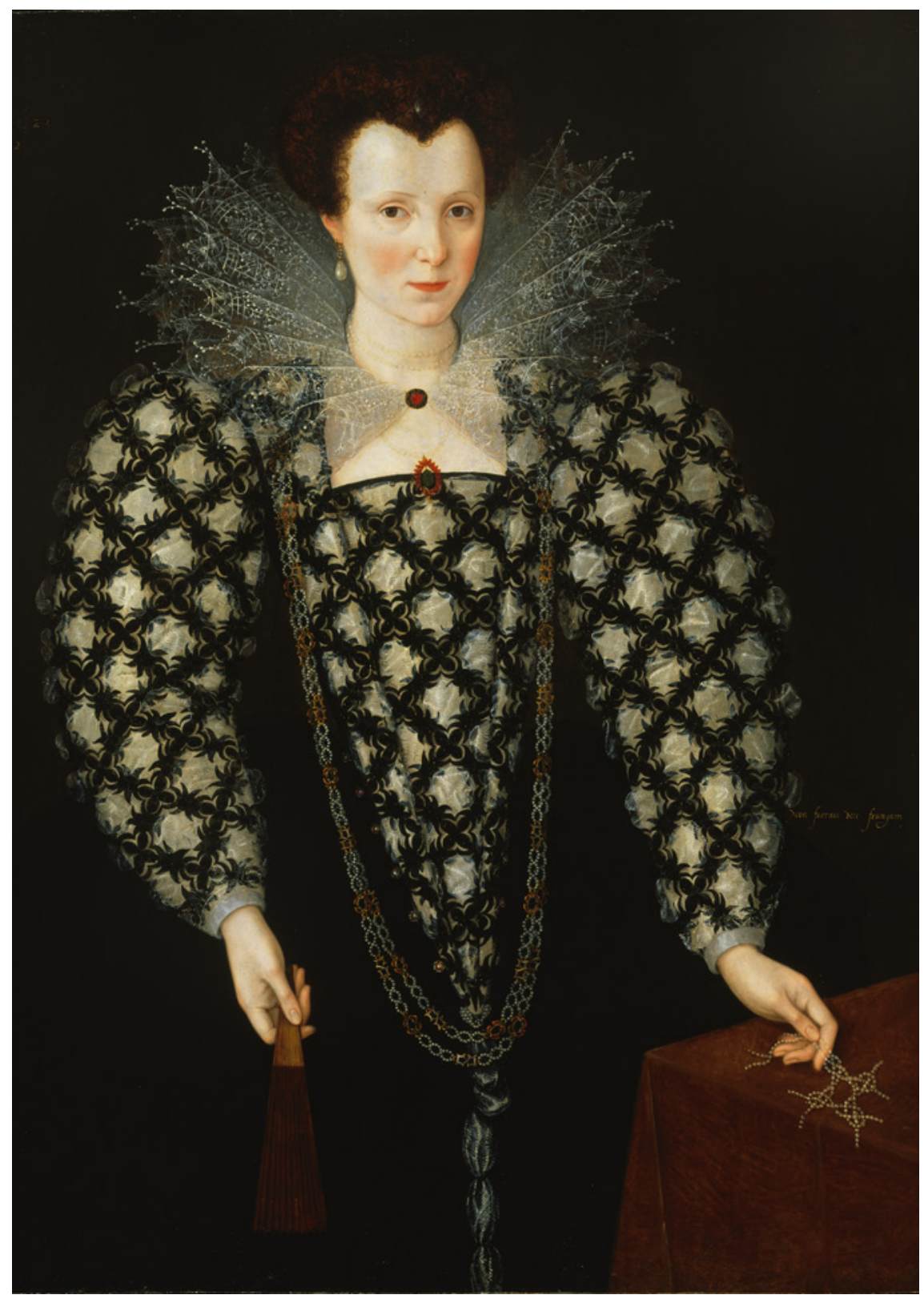

FIGURE 1 Marcus Gheeraerts the Younger, Portrait of Mary Rogers, Lady Harington, 1592, oil paint on wood. (C) TATE, LONDON. 
Harington, a young English gentlewoman, is an exemplary representation of this ageless ideal (Fig. 1). The artist Marcus Gheeraerts the Younger (1561-1636) depicted her complexion as flawless, smooth, and white; highlighted by the bright red of her lips and the rouge on her cheeks, and framed by a precious lace collar. ${ }^{3}$

The portrait may have been commissioned by her husband, the court poet Sir John Harington, on the occasion of a visit from Queen Elizabeth I (15331603 ) to their home in 1592. The queen's image politics, including her mask-like make-up, set long-lasting standards of beauty in English culture. ${ }^{4}$ Queen Elizabeth famously represented and reproduced this ageless ideal in portraits such as the Pelican Portrait (Fig. 2), attributed to the Queen's miniature painter Nicolas Hilliard (1547-1619), and dated between 1573 and 1575 .

The early modern canon of female beauty was a cultural construct set by Italian writers, such as Petrarch (1304-1374), Baldassare Castiglione (1478-1529) and Agnolo Firenzuola, and shared by English poets, including Edmund Spenser (1552/53-1599) and Philip Sidney $(1554-1586) .5$ Firenzuola provided the most detailed and rationalized description of ideal physical beauty in early

la Renaissance, exhibition catalogue, ed. Isabelle Bardiès-Fronty, et al. (Paris, 2009); Aileen Ribeiro, Facing Beauty: Painted Women \& Cosmetic Art (New Haven, 2011).

3 Due to the provenance of the painting and the piece of jewelry in her left hand with a heraldic badge of the Harington family ("Harington knots"), the sitter is tentatively identified with Lady Mary Harington (d. 1634), the wife of Sir John Harington (1561-1612), court poet to his godmother Queen Elizabeth. The Tate Gallery 1974-6: Illustrated Catalogue of Acquisitions (London, 1978), 20-1.

4 On the Pelican portrait and its pendant, the Phoenix Portrait of Queen Elizabeth, see Dynasties: Painting in Tudor and Jacobean England, 1530-1630, exhibition catalogue, ed. Karen Hearn (London, 1995), 8o. Elizabeth, exhibition catalogue, ed. Susan Doran (London, 2003); 192-3. On the image politics of Queen Elizabeth, see Roy C. Strong, Gloriana: The Portraits of Queen Elizabeth I (New York, 1987); Andrew and Catherine Belsey, "Icons of Divinity: Portraits of Elizabeth I," in Renaissance Bodies: The Human Figure in English Culture, c. 1540-166o, ed. Lucy Gent and Nigel Llewellyn (London, 1990), 11-35; Anna Riehl, The Face of Queenship: Early Modern Representations of Elizabeth I (New York, 2010); concerning her make-up, see KarimCooper, Cosmetics, $5^{8-61 .}$

5 See, with further references, Sara F. Matthews Grieco, "The Body, Appearance, and Sexuality," in A History of Women in the West: Renaissance and Enlightenment Paradoxes, eds. Nathalie Z. Davis and Arlette Farge (Cambridge, 1993), 46-84; Mary Rogers, "Beauty and Concepts of the Ideal," in A Cultural History of the Human Body in the Renaissance, eds. Linda Kalof and William Bynum (Oxford, 2010), 125-48; Edith Snook, Women, Beauty, and Power in Early Modern England: A Feminist Literary History (Basingstoke, 2011), 1-3; and in the context of medicine and health, Sandra Cavallo, Artisans of the Body in Early Modern Italy: Identities, Families and Masculinities (Manchester, 2007). 


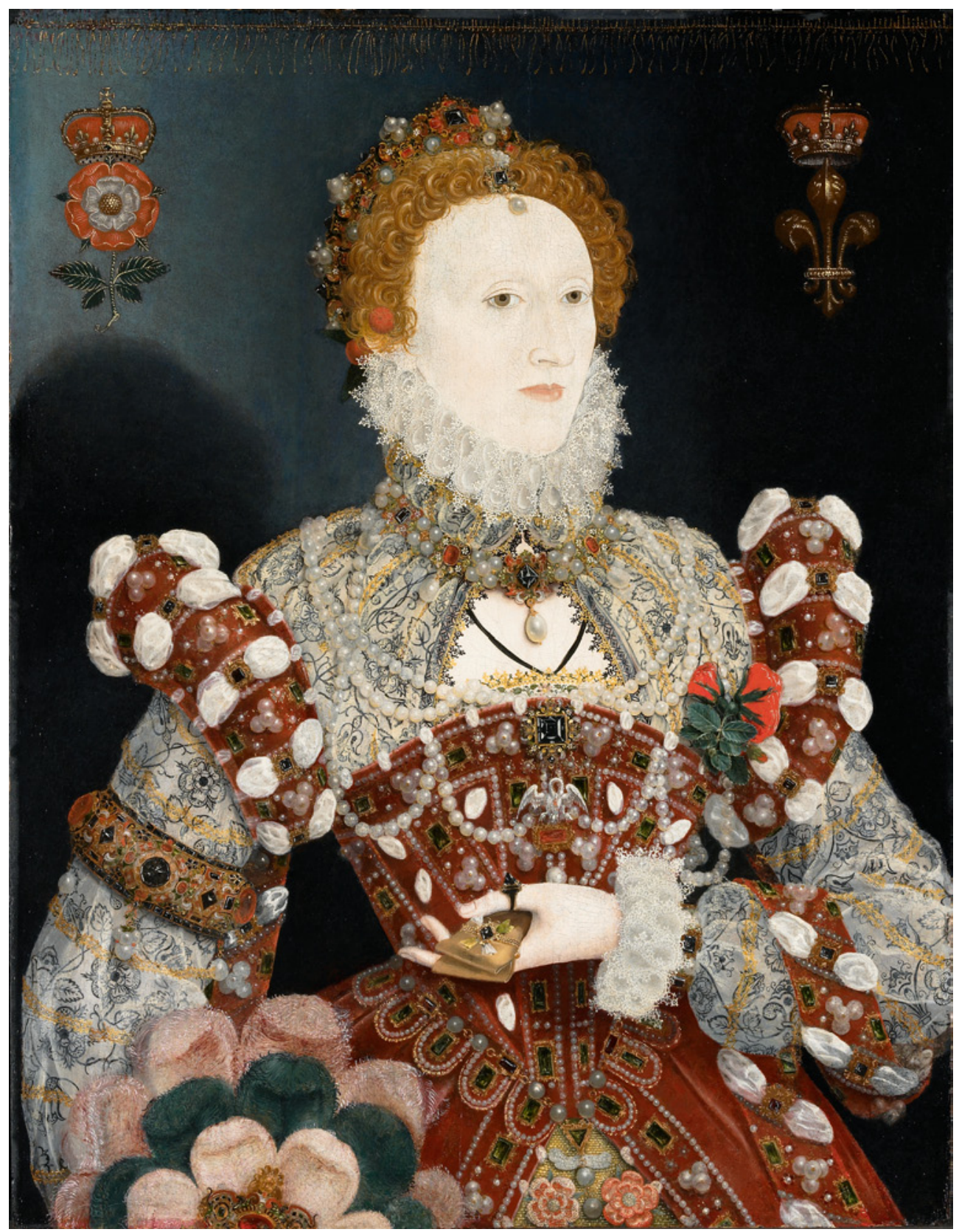

FIGURE 2 The 'Pelican' portrait, Queen Elizabeth I, ca.1575, attributed to Nicholas Hilliard, oil on panel. COURTESY NATIONAL MUSEUMS LIVERPOOL (WALKER ART GALLERY). 
modern literature. In his Dialogo delle bellezze delle donne, completed in 1541, he lists eight colors of beauty: "biondo" (blonde) and "lionato" (tawny) for the hair; "negro" (black) for the eyes; and "rosso" (red), "candido" (fair), "bianco" (white), "vermiglio" (vermillion), and "incarnato" (flesh-pink) for the lips and skin. ${ }^{7}$

Firenzuola defined the nature of these colors as visual indicators of the physiological qualities of the human body:

For, just in a body whose humors are well balanced and whose parts well arranged one finds health, and health produces a bright and lively complexion that outwardly reveals its presence within the body, so too the perfection of each specific part united in the creation of the whole will spread the color necessary for the perfect union and harmonious beauty of the entire body. 8

In this passage, Firenzuola explains beauty biologically as the external result of overall physical health. ${ }^{9}$ According to medieval and early modern humoral theory, the human physiology consisted of a mixture of four fluids - black bile, yellow bile, phlegm and blood - which influenced the human temperament and health. The four fluids of the body were equated with the four elements and with the colors black, yellow, white and red. ${ }^{10}$ Therefore, the mixture of the humors could cause color changes. Well-proportioned body fluids resulted in a pleasing complexion. Thus, in Firenzuola's palette of beauty, nature, art and medicine merge and represent more than literary topoi. Firenzuola's dialogue is also a key text in the history of the objectification of women, as women

6 Petrarca, Il Canzoniere, n. 16o, n. 9o, quoted in Agnolo Firenzuola, On the Beauty of Women, trans. Konrad Eisenbichler and Jacqueline Murray, (Philadelphia, 1992), 45. The Italian terms refer to the edition Agnolo Firenzuola, Dialogo delle bellezze delle donne (Venice, 1552), 31. On Firenzuola's text and early modern standardizations of female beauty, see Elizabeth Cropper, "On Beautiful Women: Parmigianino, Petrarchismo, and the Vernacular Style," The Art Bulletin, $5^{8}$ (1976), 374-94; Elizabeth Cropper, "The Beauty of Woman: Problems in the Rhetoric of Renaissance Portraiture," in Rewriting the Renaissance: The Discourses of Sexual Difference in Early Modern Europe, eds. Margaret W. Ferguson and Maureen Quilligan (Chicago, 1987), 175-90; Karim-Cooper, Cosmetics, 10-2.

7 Firenzuola, Beauty, 45. Firenzuola, Dialogo, 31-2.

8 Firenzuola, Beauty, 15 .

9 On this concept as well as further references, see Gadebusch Bondio, Medizinische Ästhetik.

10 For England, see also Levinus Lemnius, De habitu et constitutione corporis (Antwerp, 1559), that Thomas Newton translated in 1576 into The Touchstone of Complexions. 
are equated here with artworks. ${ }^{11}$ This misogynist analogy could be a comparative category when one considers the meaning attached to the colors of cosmetics and to those of human skin. Likewise, discourses on the colors of the human complexion in art theory and practice are comparable with discussions about the colors of beauty.

\section{Face-Painting and Art Writing}

Since Ovid declared face-painting an art in his Ars Amatoria, it has been linked with painting in its literal sense, in theory and in practice. ${ }^{12}$ Unified by color, painting on the human face and on canvas merge in terms of brushwork, painting material as well as phenomenology. ${ }^{13}$ Women's painted faces were compared with painted canvases, and women who applied cosmetics to their faces were analogized with painters. ${ }^{14}$

Unique to European visual culture, English cosmetic writings interweave traditional criticism of pictures - and the artificial - with actual art theory and experiences of artisanal practice. Moreover, England's iconoclastic periods in the 1530 s and 1640 s fostered examinations of ancient image disputes that were discussed in cosmetic treatises and art writings. ${ }^{15}$ They thus provided a critical discourse on the status of images, pictures and the visible world as a whole.

In his A tracte containing the artes of curious paintinge from 1598 (Fig. 3 ), the young English scholar and physician Richard Haydocke linked painting and

$11 \quad$ Cropper, "On Beautiful Women." For England, with further references, see, Snook, Women, 1-3; and for the beauty politics of the Queen, Riehl, The Face of Queenship.

12 Ovid, Ars amatoria 3, vv20o-234. See Molly Myerowitz, Ovid's Game of Love (Detroit, 1985), 129-49.

13 See Jacqueline Lichtenstein, Eloquence of Color (Berkeley, 1993); Karin Leonhard, Bildfelder: Stilleben und Naturstücke im 17. Jahrhundert (Berlin, 2013), 229-36.

On the link between art and cosmetics, see Wolfram Pichler, Schminke/Leinwand - Caravaggio/Goya: Selbstreflexion und Untergang des Illusionismus in Farbe (PhD diss. Vienna, 1999); Wolfram Pichler, "Schmutz und Schminke: Über Goyas Malerei," Neue Rundschau, 110 (1999), 112-30; Marguerite A. Tassi, The Scandal of Images: Iconoclasm, Eroticism, and Painting in Early Modern English Drama (Cranbury, 2005); Phillippy, Painting Women; Ribeiro, Facing Beauty; Thijs Weststeijn, "The Gender of Colors in Dutch Art Theory," in Meaning in Materials, 1400-180o, eds. Ann-Sophie Lehmann and Frits Scholten (Leiden, 2013), 176-201; Marianne Koos, Haut, Farbe und Medialität: Oberfläche im Werk von JeanÉtienne Liotard (1702-1789) (Paderborn, 2014). 


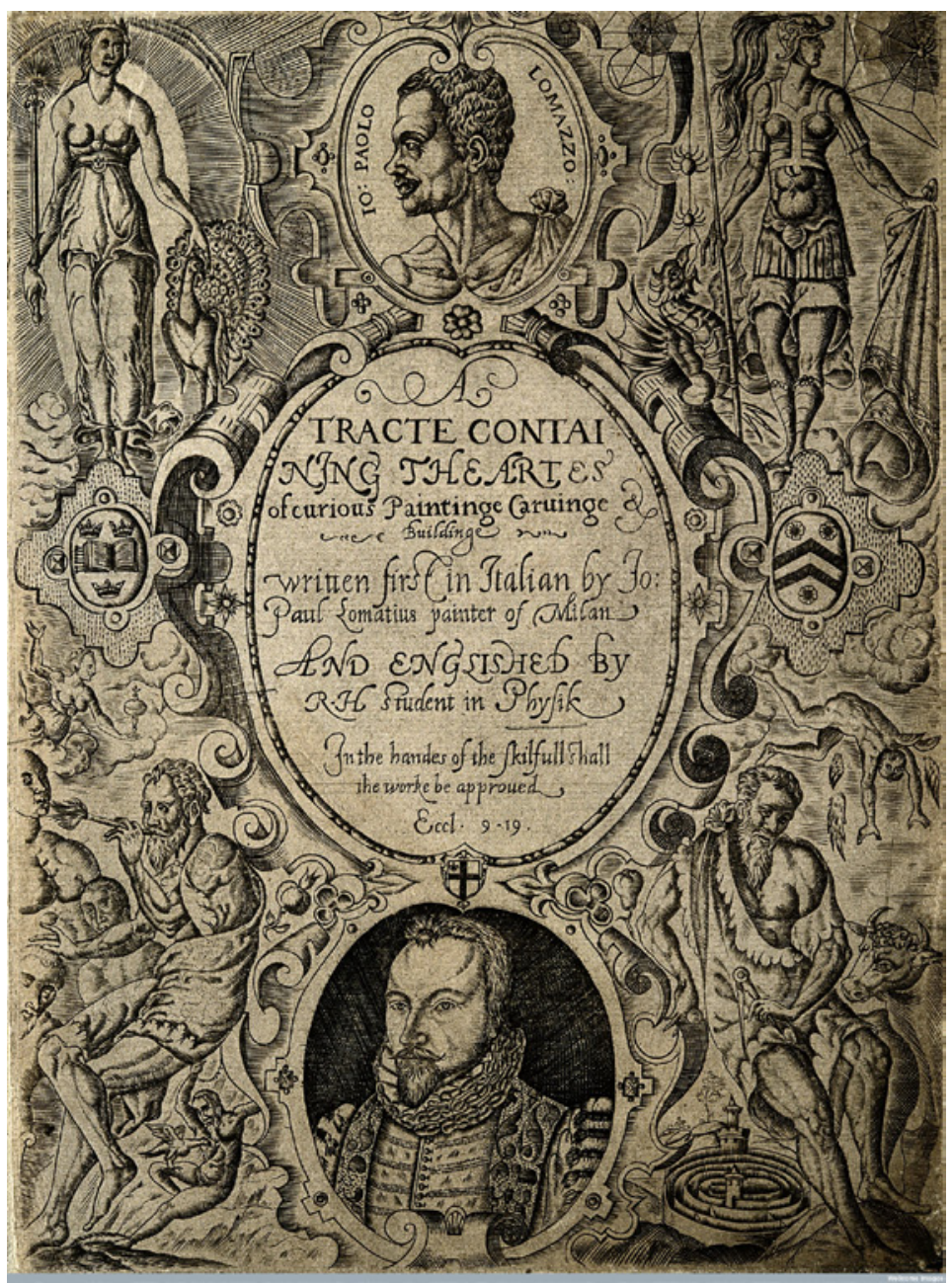

FIGURE 3 Frontispiece in: Richard Haydocke, A tracte containing the artes of curious paintinge (Oxford, 1598). (C) WELLCOME LIBRARY, LONDON.

face-painting for the very first time in English art writing. ${ }^{16}$ At that time, Haydocke, scion of a family of physicians, was studying medicine at New College in Oxford. Beyond his side interests in art and art theory, he also travelled on the European continent before graduating in 1601 . Some time after that, he settled in Salisbury as a physician. ${ }^{17}$

16 Richard Haydocke, A tracte containing the artes of curious paintinge caruinge buildinge written first in Italian by Io: Paul Lomatius painter of Milan and Englished by R.H student in physik (Oxford, 1598). A facsimile edition was published in Farnborough in 1970.

17 On the few traces of Haydocke's life, see Frederick Hard, "Richard Haydocke and Alexander Browne: Two Half-Forgotten Writers on the Art of Painting," PMLA, 55 (1940), 727-41; 
Haydocke's Tracte of paintinge provided the first English translation of the important mannerist treatise by the Italian artist Giovanni Paolo Lomazzo $(1538-1600) .{ }^{18}$ Haydocke's translation was one of the first books on painting in England. Influencing artists and writers from Nicholas Hilliard and Henry Peacham to Franciscus Junius and Horace Walpole, it was often copied and referred to in seventeenth- and eighteenth-century English art writing. Haydocke's book is well known to art historians as one of the primary texts of art writing in England. ${ }^{19}$ It is of significance for literary scholars and cultural historians in its combination of art theory and cosmetics. ${ }^{20}$ In fact, Haydocke

Elise J. Gordon, "Richard Haydocke: Physician, Engraver and Nocturnal Preacher," The Practitioner, 198 (1967), 849-54; Karl J. Höltgen, "Richard Haydocke: Translator, Engraver, Physician," The Library, 33 (1978), 15-32. As he states in his preface, Haydocke also engraved the frontispiece with a profile bust of Lomazzo above the title cartouche in the center and his self-portrait below. Haydocke, Tracte, preface, n.p. For the frontispiece, see Margery Corbett and Ronald W. Lightbown, The Comely Frontispiece: The Emblematic Title-page in England 1550-1660 (London, 1979), 67-79. On Haydocke's engravings, see Gordon, "Haydocke"; Höltgen, "Haydocke”; Karl J. Höltgen, "An Unknown Manuscript Translation by John Thorpe of du Cerceau's Perspective," in England and the Continental Renaissance: Essays in Honour of J.B. Trapp, eds. Edward Chaney and Joseph B. Trapp (Woodbridge, 1990), 215; Craig A. Hanson, The English Virtuoso: Art, Medicine, and Antiquarianism in the Age of Empiricism (Chicago, 2008), 42-5.

18 On the reception of Lomazzo's treatise in Europe, see Gerald M. Ackerman, "Lomazzo's Treatise on Painting," The Art Bulletin, 49 (1967), 317-26; Martin Kemp, "Equal Excellences': Lomazzo and the Explanation of Individual Style in the Visual Arts," Renaissance Studies, 1 (1987), 1-26.

19 Hard, "Richard Haydocke"; John Pope-Hennessy, "Nicholas Hilliard and Mannerist Art Theory," Journal of the Warburg and Courtauld Institutes, 6 (1943), 89-100; Luigi Salerno, "Seventeenth-Century English Literature on Painting," Journal of the Warburg and Courtauld Institutes, 14 (1951), 234-58; Rosamond D. Harley, Artists' Pigments, c. 1600-1835: A Study in English Documentary Sources (London, 2001 [1970]), 5; Alistair Moffat, Lomazzo's Treatise in England in the Late Sixteenth and Early Seventeenth Centuries, (PhD diss., London, 1975); Lucy Gent, "Haydocke's Copy of Lomazzo's Trattato," The Library, 1 (1979), 76-81; Lucy Gent, Picture and Poetry, 1560-1620: Relations between Literature and the Visual Arts in the English Renaissance (Leamington Spa, 1981); Mansfield Kirby Talley, Portrait Painting in England: Studies in the Technical Literature before 1700 (London, 1981) 22-9; Michael Baxandall, "English Disegno," in England and the Continental Renaissance, eds. Chaney and Trapp, 203-13; Ribeiro, Facing Beauty, 134.

20 John R. Hale, England and the Italian Renaissance: The Growth of Interest in its History and Art (Malden, 2005 [1954]), 47; Tassi, Scandal of Images, 46-53; Farah Karim-Cooper, Cosmetics, 44-6; Hanson, English Virtuoso, 39-52; Edith Snook, "The Beautifying Part of Physic': Women's Cosmetic Practices in Early Modern England," Journal of Women's History, 20 (2008), 10-33; Bruce R. Smith, The Key of Green: Passion and Perception in Renaissance Culture (Chicago, 2009), 62-3; Ribeiro, Facing Beauty, 134; Snook, Women, 99; 34. 


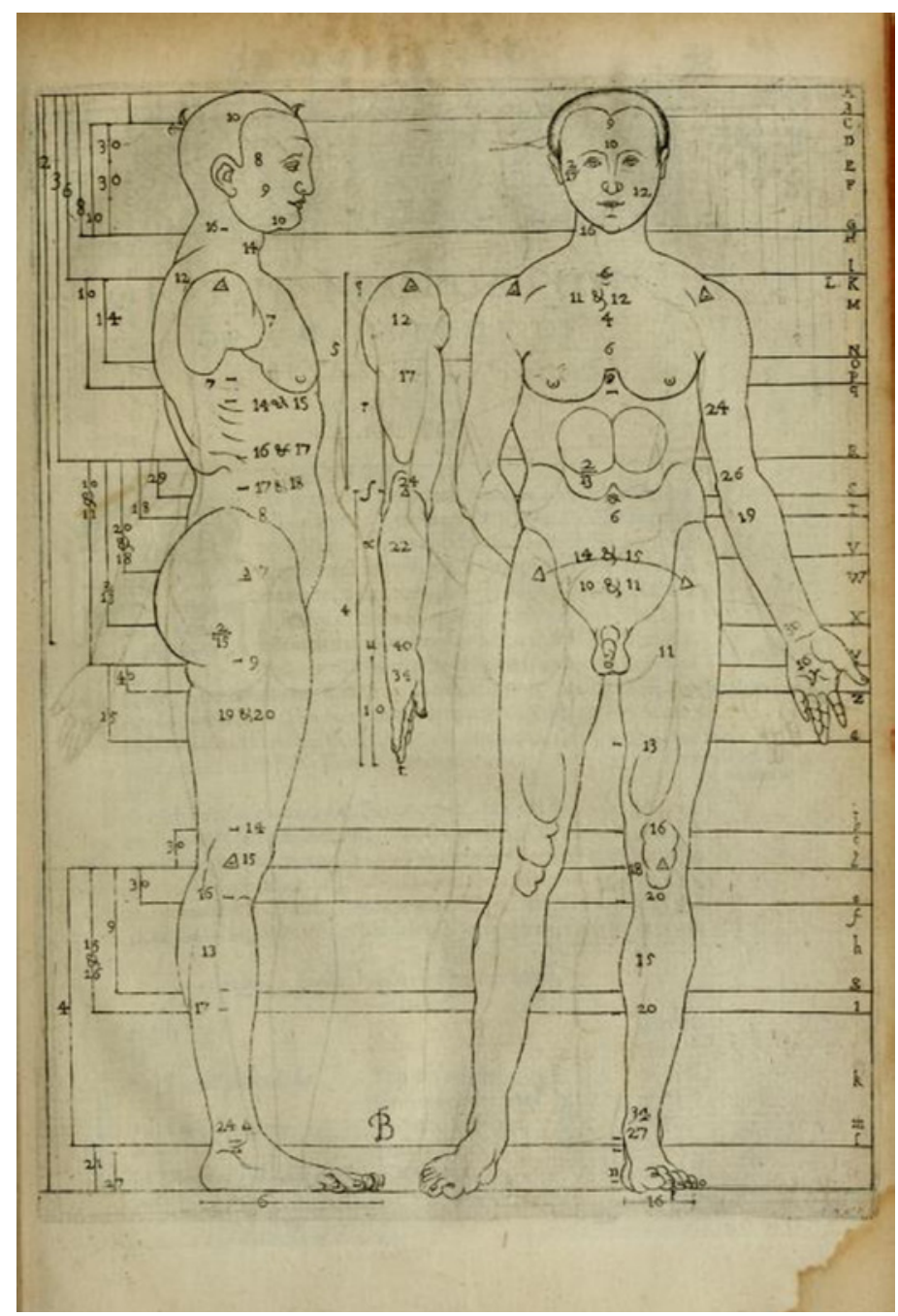

FIGURE 4 Table B in: Richard Haydocke, A tracte containing the artes of curious paintinge (Oxford, 1598). (C) BRITISH MUSEUM, LONDON.

translated and provided a commentary on the first five of Lomazzo's treatises, on proportion, passions, color, light and perspective (omitting those on composition and iconography). A preface, a glossary of art theoretical terms and a letter to the author frame Lomazzo's master text. Haydocke also supplied the frontispiece, a self-portrait and the chapters on proportion and perspective with his own graphic works (Fig. 4), which are based on Albrecht Dürer's Vier Bücher menschlicher Proportion (1528) (Fig. 5). 


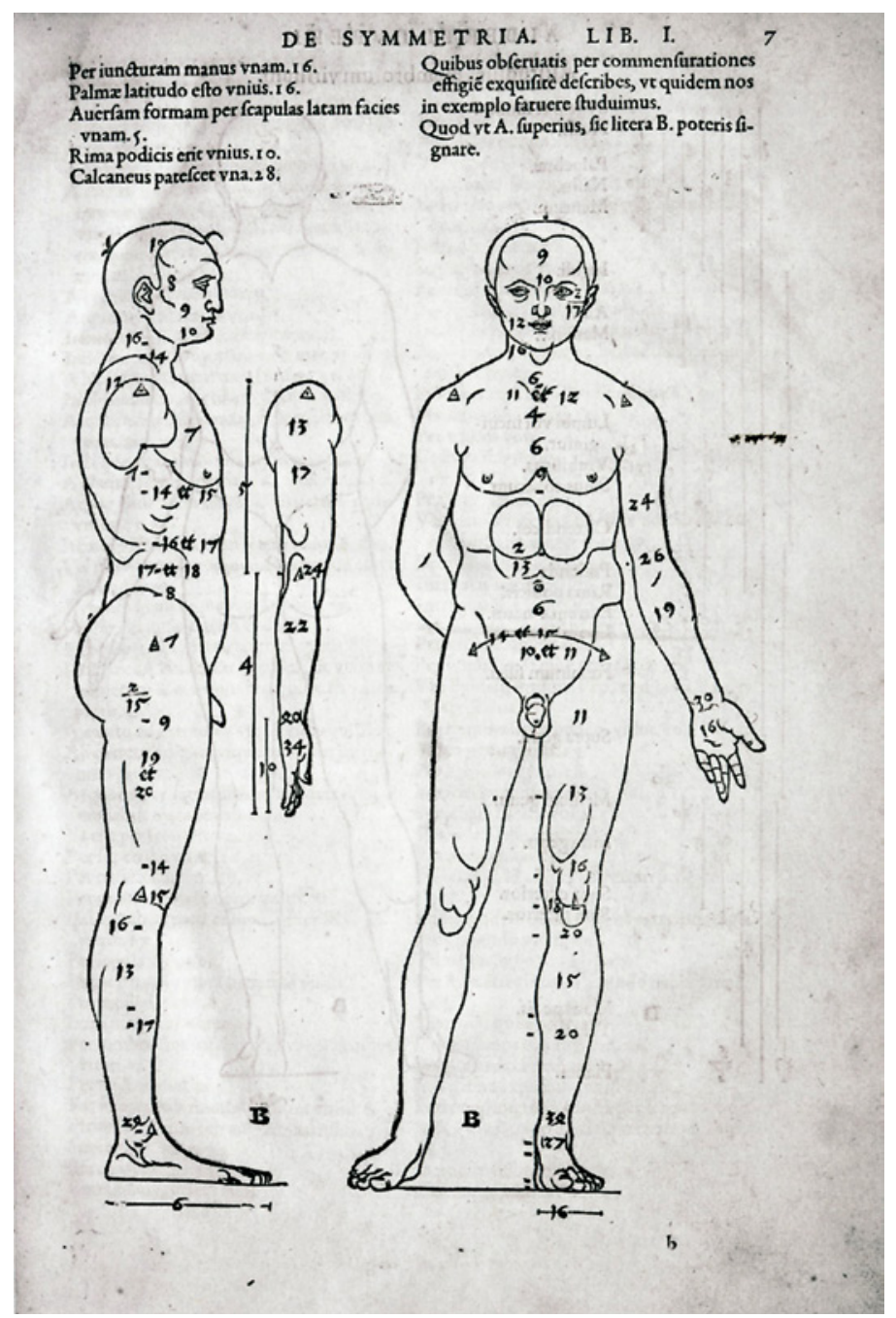

FIgURE 5 Table B in: Albrecht Dürer, Della simmetria dei corpi humani, trans. Giovanni Paolo Galluccio (Venice, 1594). AUTHOR'S ARCHIVE.

Moreover, he added an independent chapter entitled "A Briefe Censure of the Booke of Colours," containing paragraphs on color, wall painting and facepainting. ${ }^{21}$ By providing a theoretical and a practical account of cosmetics, including a definition of color, this book on color presents evidence in support of a link between cosmetic colors and artist colors in seventeenth-century

21 On Haydocke's omissions, additions, and adaptions for an English Protestant readership, see Haydocke, Tracte, preface, n.p.; and the discussion of Hanson, English Virtuoso, 40. 
writings. It also reveals Haydocke's translation to be the result of a transfer process from Italian theory to English culture. ${ }^{22}$

\section{Lomazzo's Book on Colors}

The third book of Lomazzo's Italian Trattato dell'arte della pittura assesses color. $^{23}$ His comprehensive approach provides discussions of knowledge of colors, the materials and techniques used to effect color changes as well as their semantic meanings. Eight chapters on individual colors - namely, black, white, red, the "colour of the peacocke," yellow, green and blue - give an overview of their meanings in hermeneutics, optics and history. ${ }^{24}$ Considering several overlapping concepts of color, Moše Baraš, in his study of color in Renaissance art theory, examines three different meanings of color in Lomazzo's text: an empirical-optical concept of body colors in the Peripatetic tradition as well as concepts of colors as symbols and as painting materials. ${ }^{25}$ Firstly, referring to Aristotle, Lomazzo describes color as the visible quality of the surface of an object independent of light. ${ }^{26}$ The generation of colors was explained on the basis of the Aristotelian theory of the elements. Lomazzo quotes from the popular account on color mixing in pseudo-Aristotle's De Coloribus: "Cold

22 For English-Italian translations in sixteenth-century England, see Michael Wyatt, The Italian Encounter with Tudor England: A Cultural Politics of Translation (Cambridge, 2005); for the relation of translation and knowledge in the seventeenth-century Arundel court, see also Thijs Weststeijn, "Translating 'Schilderspraeke': Painters' Terminology in the Dutch Edition of Franciscus Junius's The Painting of the Ancients (1637-1641)," in Translating Knowledge in the Early Modern Low Countries, eds. Harold J. Cook and Sven Dupré (Zurich, 2012), 163-96. For the question of artistic knowledge exchange, Heiko Damm, Michael Thimann, and Claus Zittel, "Introduction: Close and Extensive Reading among Artists in the Early Modern Period," in The Artist as Reader: On Education and Non-Education of Early Modern Artists, ed. id. (Leiden, 2013), 1-68.

Giovanni Paolo Lomazzo, Trattato dell'arte della pittura, scoltura, et architettura (Milan, 1585), 187-210.

24 Haydocke, Tracte, III, 98: "[...] There be 7 sortes of simple colours, from which all the rest arise. Of these 2 are extreames, as white \& Blackes, and 5 middle, as light yeallow, redde, purple, Blewe and Greene."

On Lomazzo's color concept, see Moše Baraš, Light and Color in the Italian Renaissance Theory of Art, (New York, 1978), 135-209; Kemp, "Equal excellences," 269-72.

26 Lomazzo, Trattato, 190. "Aristotle defineth Colour to be a visible qualitie limited \& bounded in the surface or extremity of a darke body, which before it be lighted is visible onely in possibility \& by the benefit of the light may be actually seen." Haydocke, Tracte, III, 98. Baraš, Light and Color, 161, notes that this concept might refer to the reference to the Pythagoreans in De Sensu, 439a. Cf. "But since colour is at the extremity of the body, it must be at the extremity of the transparent in the body." Aristotle, "Sense and Sensibilia," in The Complete Works of Aristotle, ed. Jonathan Barnes (Princeton, 1985), 1: 698 [439b]. 
produceth white, whereunto much light is required. Heate ingendreth Blacke, proceeding from a small quantity of light and much heate. Red is made by the mixture of white, and blacke."27 Secondly, in his Trattato dell'arte, he discusses an iconology of colors, which includes their power to convey and affect passions based on the relation between planets, colors and passions. ${ }^{28}$

Beside these aspects of immaterial colors (colores apparentes), Lomazzo also takes into account humoral theory in relation to color and coloration another field in which art and medicine converge. For the very first time in art writing, Lomazzo considers humoral theory in a practical way by explaining how to portray a person's physiological condition. ${ }^{29}$ As mentioned above, according to medieval and early modern humoral theory, beginning with Hippocrates, a good balance of the four fluids of the body (the four humors, which belonged to the res naturales: black bile, yellow bile, phlegm and blood) and their qualities (cold/dry, warm/dry, cold/moisture, warm/moisture) form the basis of human health. The balance of the fluids was influenced by the environment, planets and stars (res non naturales). ${ }^{30}$ The humoral fluids were related to the four elements and the colors black, yellow, white and red. According

27 Following the peripatetic treatise de coloribus, Haydocke, Tracte, III, 98. Lomazzo, Trattato, 190-1. On the influence of de coloribus on early modern color theory, see, with further reference, Martin Kemp, The Science of Art, 264-84; Leonhard, Bildfelder, 339-41.

28 Lomazzo, Trattato, 201-2. Haydocke, Tracte, III, 112. See Baraš, Light and Color, 165-9, who notes that Lomazzo translated passages from Heinrich Cornelius Agrippa von Nettesheim's popular book on natural history and magic, De occulta philosophia. Cf. note 41 on Haydocke's sources.

29 Simone Pòrzio in his commentary of De coloribus, printed in 1548, for example, did not refer to classical humors. Don Pavey, Colour and Humanism: Colour Expression and Patterns of Thought about Colour (USA, 2003 [1956]), 145, concludes that "the idea of the physical coloration of the flesh through the agency of the temperaments became concrete enough in the popular mind for Lomazzo to apply it to painting [...]" See also Baraš, Light and Color, 162, who explains this focus with the scientific tradition of sixteenth-century Milan; and Frank Fehrenbach, "Calor Nativus-Color vitale: Prolegomena zu einer Ästhetik des 'Lebendigen Bildes' in der frühen Neuzeit," in Visuelle Topoi: Erfindung und tradiertes Wissen in den Künsten der italienischen Renaissance, eds. Ulrich Pfisterer and Max Seidel (Munich, 2003), 159-61.

30 Haydocke, Tracte, II, 12: “[...] every body is composed of the foure humors, which represent the foure elements; as Melancholie resembling the earth: fleame the water: Choler the fier: and bloud the aire." Cf. Lomazzo, Trattato, 113. For the influence of humoral theory on color concepts in art (writing), see Raymond Klibansky, Erwin Panofsky, and Fritz Saxl, Saturn and Melancholy: Studies in the History of Natural Philosophy, Religion and Art (London, 1964); John Gage, "A Locus Classicus of Colour Theory: The Fortunes of Apelles," Journal of the Warburg and Courtauld Institutes, 44 (1981), 1-26; Tanja Klemm, Bildphysiologie: Wahrnehmung und Körper in Mittelalter und Renaissance (Berlin, 2013). 
to Lomazzo, the humoral tempers - melancholic, choleric, phlegmatic, and sanguine - can be represented by compositions of the four humoral colors. ${ }^{31}$ Conversely, the sight of colors can influence the human condition. Reddish colors, for instance, "cause courage, providence, fiercenesse and boldnesse by stirring up the minde like fire."32 Lomazzo's combination of color and humoral theories, in sum, links the appearance of a person and his or her artistic representation on both a physiological and artistic level. This link between art and body may have been what intrigued the young medical student, Haydocke.

\section{From Hippocrates to Apelles: Haydocke's Translation}

The section added by Haydocke entitled "A Briefe Censure of the Booke of Colours" is, in short, a summary of Haydocke's adaptation of the complex Italian master text for English culture. In his preface, Haydocke himself explicates that his Tracte of paintinge is more than a 'mere' translation. Haydocke describes Lomazzo's master text as only a "Shaddowing Muse" for his writing. ${ }^{33}$

Regarding Haydocke's text in comparison with Lomazzo's treatise, Lucy Gent, and subsequently Michael Baxandall, argue that Haydocke does not manage to recognize the comprehensive meaning of the mannerist concept of disegno, which refers to both an idea and its graphic realization. Instead, he used "disegno" in terms of "draft," like the French "dessin." ${ }^{34}$ Therefore, Haydocke's "Briefe Censure" both narrows and broadens the treatise's focus on art: narrows, because this misunderstanding failed to introduce an important concept, which would have affected subsequent art writing in seventeenthcentury England; broadens, in that, instead of adapting the Italian disegnomodel, he stresses color and techniques of color application by detailing the materiality of color substances and the consequences of their use, including in face-painting. His explanation of the meaning of color defines painting anthropologically as being created by the act of applying color: ${ }^{35}$

Based on a compound of black, yellow, white, and red-yellow, Lomazzo gave detailed explanations of how to paint these humoral types by gradually decreasing the amount of white - from the complexion of the choleric man, composed of two parts red, one part yellow, and three parts "fair" (chiaro); and sanguine skin, consisting of two parts red, one part yellow, and two parts "fair"; to the phlegmatic, with only one part "fair"; and the absence of white and red in the melancholic complexion. Lomazzo, Trattato, 300-1. Haydocke, Tracte, III, 112.

33 Haydocke, Tracte, preface.

34 Gent, Picture and Poetry. Baxandall, "English Disegno." On disegno in sixteenth-century art theory, see Wolfgang Kemp, "Disegno: Beiträge zur Geschichte des Begriffs zwischen 1547 und 1607," Marburger Jahrbuch für Kunstwissenschaft, 19 (1974), 219-40. 
Colour is a materiall substance, indued with a qualitie diversly affecting the eie, according to the matter wherein it is founde. That it is a materiall substance he [Lomazzo] prooveth in chap. 4. where he handleth the matters whereof colours are made, shewing that some of them are taken from minerals and earths, some from the vegetables, and some from the animals. All wich, because they are of diverse natures, require a severall handling, as wel in their working, as in their mixtures. ${ }^{36}$

Based on Lomazzo's complex discourse, Haydocke concludes that color can be defined as a "material substance," whose condition determines visual perception. ${ }^{37}$ Lomazzo explains the representation of the colors of nature in the sixth book on practice, which Haydocke did not translate: ${ }^{38}$ Lomazzo defines color peripatetically as the visible quality of a surface perceived through light. He carries out a naturalistic concept of colored bodies, whose perception depends on the light refraction of the color material, the binding and mixtures of color materials. ${ }^{39} \mathrm{Up}$ to this point, Haydocke distinguishes between material and immaterial colors in a traditional manner, by describing immaterial colors (colores apparentes) and material colors (colores proprii). ${ }^{40}$ At this point, however, he goes further than Lomazzo and stresses the importance of knowledge about artistic materials and techniques regarding the physical effects of color substances. ${ }^{41}$ Introducing different examples of practicability, he discusses

$36 \quad$ Ibid. Accentuations by Haydocke.

37 Ibid.

38 Lomazzo, Trattato, 299: “[...] non sono dell'opinione di quelli filosofi Periparetici, che dicono non esserui alcun' colore, quando non vi è lume, \& chiarezza che allumi i colori. Anzi dico liberamente, che i raggi, è lume del Sole, ò di qual si voglia altra luce, non generano, ò producono i colori; perche innanzi che vi concorra la luce, stanno già attualmente prodotti nel soggetto. $\mathrm{E}$ ben vero che la luce causa questo effetto, che fa vedere il colore attualmente; ilquale innanzi l'auuenimento della luce, era solamente visibile. [...] percio il pittore, non hà da dipingere mai il colore tutto solo; mà sempre lo hò da dipingere allumate, cioè con gli vari effetti che causano la luce non riceuuta egualemente no' colorati." What follows are details about the color and composition of the complexion attributed to the four humors.

39 Haydocke, Tracte, III, 125: "[...] We shall finde it not altogither so apt for the use of the unexperienced Painter, aswell in regarde of the definitiom of colour, as also of the division thereof; both which are meerely Philosophical, expressing rather the conceived nature of Colour, by way of abstraction from the sense [...]." Cf. the discussion of Hanson, English Virtuoso, 41.

40 See, in nuce, Leonhard, Bildfelder, 358-61.

41 Already Haydocke's preface names these sources besides Lomazzo's mastertext: Heinrich Cornelius Agrippa von Nettesheim's De vanitate et incertitudine scientiarum (1527); 
different painting techniques, i.e., limning, oil, fresco painting - and facepainting. The subsequent chapters attend to wall painting and face-painting; the latter is entitled "Of the painting of women" and is followed by a "Discourse of the artificiall beauty of women," as well as chapters on the ingredients used to make certain cosmetic preparations and their effect on the human skin. ${ }^{42}$ With the exception of face-painting, these passages on painting techniques refer to two sources: first, Haydocke's account of painting techniques leads to yet another popular art-historical book from Italy, Giorgio Vasari's (1511-1574) Lives of the Artists. ${ }^{43}$ In the chapter on fresco painting, Haydocke uses the exact words from Vasari's Lives. ${ }^{44}$ The second field is practical; the passages on limning name the contemporary portrait painter Nicholas Hilliard, the "Raphaell" of limning, and his pupil Isaac Oliver (ca. 1565-1617) as models. In his preface, Haydocke announces Hilliard's forthcoming treatise on painting practice. Haydocke's Tracte went on to become Hilliard's theoretical reference. ${ }^{45}$

Regarding Haydocke's definition of painting mentioned above, this practical account seems to narrow his concept of painting to the act of applying color to the human face. In focusing on face-painting, he also links art and medicine together at a point at which they intersect - namely, the human body.

With regard to the color concept presented in the "Briefe Censure," Haydocke refers to the traditional classification of material and immaterial colors,

Giovanni Paolo Galluccio's Italian translation of Albrecht Dürer's treatise on proportion, Della simmetria dei corpi humani (1591); Lomazzo's Idea del tempio della pittura (1590); Giovanni Battista Armenini's treatise De'veri precetti della pittura (1587); Giorgio Vasari's Lives of the Artists (1568); the English translation of Ludovico Ariosto's Orlando Furioso by John Harington, Lady Mary Harington's husband; Aristotle's Politics, Baldassare Castiglione's book on the courtier Il Cortigiano (1528).

42 Haydocke, Tracte, III, 127-133.

43 Ibid., 125-126. Haydocke owned a rare copy of Vasari's Vite. He later donated it to the Bodleian Library, where it can be found in the Benefactor's Register of 1601. Höltgen, "Richard Haydocke," 18. Alexander Marr: "Curious and Useful Buildings.' The Mathematical Model of Sir Clement Edmondes," The Bodleian Library Record, 18 (2003), 108-150, here 128.

44 Giorgio Vasari, Le vite de' piv eccellenti pittori, scvltori, et architettori (Florence, 1568), 50, "Cap. XIX Del dipingere in muro, come si fa e perché si chiama lavorare in fresco."

45 Haydocke, Tracte, preface. Hilliard's Arte of Limning was written after 1598 and before 1603, probably intended for publication. However, the treatise was only printed by Philip Norman, "Introductory Note on Nicolas Hilliard's Treatise Concerning 'The Art of Limning," The Volume of the Walpole Society, 1 (1911-1912), 1-54. On Hilliard's place in art theory and the Lomazzo's influence, see Pope-Hennessy, Nicholas Hilliard. 
which clarifies his approach to artistic colors, but not his concept of cosmetics colors.

\section{Cosmetic Sources - Cosmetic Recipes}

\section{Haydocke's Concept of Cosmetics}

As we have already seen, face-painting refers to the ancient ars comptoria or ars decoratoria, the techniques of embellishing one's external appearance by applying paint. ${ }^{46}$ In contrast to this more superficial concept of improvement, the antique cosmetica medicamenta referred to the application of (medicinal) substances to the skin. Still, in the early modern period, cosmetic writings often distinguished terminologically between cosmetics and paint. ${ }^{47}$ Accordingly, Haydocke notes a difference between recommendable cosmetica medicamenta and less acceptable ars comptoria:

This Arte consisteth of a twoofold method; either by way of preparation and abstertion, of some naturall or adventitious imperfections of the skinne, which is done with fomentations, waters, ointments, plaisters, and other matters, which I meane not to prescribe, or by a more grosse illiture and laying on of materiall colours; whereby such unpleasing defectes are rather covered then abolished and taken away. ${ }^{48}$

This notion of cosmetics includes all methods that alter the color of the skin by means of applying pharmaceutical substances: either preparations that change the complexion itself, such as "fomentations, waters" and "ointments," or paint ("materiall colours") that covers the skin. Preparations such as waters and ointments belong to the field of cosmetica medicamenta; paint, to ars comptoria. Haydocke, however, does not distinguish between the two fields in discussing cosmetic ingredients. Concentrating on individual examples of harmful substances in cosmetic recipes, he includes short chapters on quicksilver, white lead ("cerusse"), alum, citric acid ("lemon juice"), potash ("tartaric oil"), as well

46 Galen, De compositione medicamentorum secundum locos, 14, vv52-57, as well as Ovid, Ars amatoria 3: 200-34. In contrast, Samuel Johnson defined "cosmeticks" simply as "the power of improving beauty." Samuel Johnson, A Dictionary of the English Language (London 1755-1756), 1: n.p. On the history of this concept, see Gadebusch Bondio, Medizinische Ästhetik.

47 However, the terms sometimes overlapped. Cf. Snook, "Beautifying Part," 13-4.

48 Haydocke, Tracte, III, 127. 
as niter ("salnitrum"), and "of all such thinges as are enemies to health, and hurtfull to the complexion," especially those "paintings and embellishings which are made with minerals, and corrosives." 49

With the exception of white lead, these ingredients probably did not effect a change in color the way applying paint does. As they belong to the field of pharmacology (materia medica), however, they may have altered the appearance of the complexion by provoking a physiological response.

Considering the medicinal use of toxic metals (lead, mercurous chloride) as preservatives and for anti-inflammatory purposes, Haydocke stresses the sideeffects of these substances: they may cause irritation and corrode the skin, making it appear reddish. Also, niter may be used as a preservative (as in cooking). In addition to these irritating effects, the metals alum and citric acid may also have a whitening effect on the complexion by altering the skin's pigmentation.

For Haydocke, these substances are harmful not only because they are toxic, corrosive and irritating, but also because they generate physiological reactions that alter the complexion. Haydocke concludes his "Briefe Censure of the Booke on Colours" with a short list of what may be applied without posing any health risks. This list is thus based on qualities of virtue that may also beautify the physical appearance: contentment, health, honesty and wisdom will always outshine face-paint.

Indeed, cosmetic recipes were included in general collections of remedies and belonged to the field of body care and dietetics. In her studies of early modern cosmetics, Edith Snook notes that, in terms of "beautifying physic," cosmetics were related to the "medical culture, diagnosis and treatment" in early modern England. ${ }^{50}$ According to the comprehensive humoral model, efforts to improve the physical appearance had a physiological effect on the whole body. Furthermore, it gave attempts at embellishment a "physical and emotional logic" in contrast to the "theatrical" and "performative" nature of paint. 51

Nevertheless, cosmetic recipes used terms such as "fucus" and "pomatum" interchangeably for face-paints as well as medicines. ${ }^{52}$ Such preparations simultaneously covered and transformed, and contained the very ingredients Haydocke warned against. ${ }^{53}$

\footnotetext{
49 Ibid., 132. On harmfulness as a trope in cosmetic writings, see Phillippy, Painting Women, 7-9.

$50 \quad$ Snook, "Beautifying Part," 13.

51 Snook, Women, Beauty and Power, 28.

$5^{2}$ Snook, "Beautifying Part," 13.

53 On colors as pharmakeia, see Lichtenstein, Eloquence of Colour, 52; Karin Leonhard,
} 


\section{From Hippocrates to Apelles - Haydocke's Sources}

Discussions about the painted face in early modern cosmetic writings challenged the relation between art and nature in the process of artistic creation. In his chapter on "The painting of women," Haydocke uses terms from art writing, such as "Arte of Colouring," "Naturall," and "Artificiall" to describe make-up. ${ }^{54}$ Indeed, in contrast to the painter's "Colouring by the life," he defines face-painting as "Painting upon the Life where a knowne naturall shape is defaced, that an unknowne Artificiall here may be brought thereon."55 Linking the creation of art and cosmetics, this passage refers to a misogynist, key anti-cosmetic argument, which has existed since late antiquity. Early Christian theologians, from Tertullian and Cyprian to Ambrose, deemed face-painting a female occupation and denounced it as a distortion of the human face with paint because it falsifies humankind's divine creation in God's image. ${ }^{56}$ Haydocke's account resumes this dispute, although he does not criticize cosmetics and face-painting per se but their abuse, as well as people's ignorance and lack of knowledge regarding the ingredients involved ("unknowne Artificall").57

Due to the negative side effects cosmetic ingredients could have on the physical condition, Haydocke's goal (as a physician) was to discuss the "nature" and "qualities" of these substances so as to prevent further damage resulting from people's ignorance. ${ }^{58}$ In contrast, he briefly summarized, among other things, ointments, waters, and plasters as recommended means of improving one's physical appearance. Instead of giving examples of advisable cosmetics, he refers readers to one of his sources, a collection of cosmetic recipes he

"Painted Poison: Venomous Beasts, Herbs, Gems, and Baroque Colour Theory," Nederlands Kunsthistorisch Jaarboek, 61 (2011), 116-47; Leonhard, Bildfelder, 180-1.

54 Haydocke, Tracte, III, 127.

55 Ibid. Cf. Hanson, English Virtuoso, 41.

$56 \quad$ E.g., Tertullian, De cultu feminarum, 2, 5 2-4 (II. 5: 2-4); Cyprianus, De habitu virginum, 15; Ambrosius, Hexaemeron, 6, 8, 47. See, in nuce, Löhr, "Korrekturen"; for anti-cosmetics treatises in early modern English literature, see Frances E. Dolan, "Taking the Pencil out of God's Hand: Art, Nature, and the Face-Painting Debate in Early Modern England," PMLA, 108 (1993), 224-39.

57 Haydocke, Tracte, III, 127.

58 Cf. Leonardo Fioravanti, Dello specchio di scientia universale (Venice, 1564), 305: “[...] in questo mio trattato ragionerò solamente della natura di alcune cose, che le donne usano di continouo per farsi belle; percioche molte volte in luogo di farsi belle, si fanno bruttissime, e questo auuiene solo per non sapere la natura, \& qualità dei materiali." ([...] in my treatise, I will only discuss the nature of several things that the women use all the time to embellish themselves, for this reason [it happens] often that for embellishment, they uglify themselves, and this only happens because of a lack of knowledge of the nature and quality of their materials.) 
called "The ornaments of women" by "John Modonese Doctor of Physicke's" Giovanni Marinello's Gli ornamenti delle Donne. ${ }^{59}$

Haydocke's chapters on cosmetics referred to a classical tradition of recipes ranging from Dioscorides' Materia medica, Pliny's Naturalis historiae and Ovid's Medicamina Faciei Femineae to sixteenth-century publications on natural history. ${ }^{60}$ Haydocke himself mentions two sources for his chapters on cosmetics. ${ }^{61}$ First, the Dello specchio di scientia universale (Mirror of Universal Science) by the Bolognese physician Leonardo Fioravanti, first published in Venice in 1564. In fact, Haydocke uses the very same wording as used in Fioravanti's chapter on belletti for his chapter on cosmetic ingredients. ${ }^{62}$ Secondly, Haydocke refers to Giovanni Marinello's previously mentioned recipe collection, Gli ornamenti delle Donne. ${ }^{63}$

These sources are part of an important range of early modern writings on cosmetics, including printed recipe collections in 'books of secrets'. This term refers to a genre of early modern collections of empirical knowledge in the vernacular - how-to books - which flourished in the second half of the sixteenth century. ${ }^{64}$

Based on these sources, Haydocke's concept of cosmetics corresponds with the traditional structure of medical decorative arts (ars decorativa), in other words, techniques of physical embellishment and attempts at maintaining or

59 Haydocke, Tracte, III, 129. Giovanni Marinello, Gli ornamenti delle Donne: Tratti dalle Scritture d'una Reina Greca (Venice, 1562). On Marinello, see Mariacarla Gadebusch Bondio, "Piacevoli ragionamenti e medicina per le donne: Giovanni Marinello, medico galante del tardo Cinquecento," Medicina nei secoli, 11 (1999), 55-84; Phillippy, Painting Women, 6.

6 o Gadebusch Bondio, Medizinische Ästhetik.

61 Haydocke, Tracte, III, 129.

62 Leonardo Fioravanti, Del Compendio de i secreti rationali, (Venice, 1564), 431-40. Haydocke, Tracte, III, 132. On harmfulness as a trope in cosmetic writings, see Phillippy, Painting Women, 7-9; as a strategy of female exclusion from medicine, Snook, "The Beautifying Part"; Snook, Women, 28-35.

63 Haydocke, Tracte, III, 129. Marinello, Gli ornamenti.

64 On the medical tradition in books of secrets, see John Ferguson, Bibliographical Notes on the Histories of Inventions and Books of Secrets (London, 1981); William Eamon, Science and the Secrets of Nature: Books of Secrets in Medieval and Early Modern Culture (Princeton, 1994); Allison Kavey, Books of Secrets: Natural Philosophy in England, 1550-1600 (Urbana, 2007); William Eamon, "How to Read a Book of Secrets," in Secrets and Knowledge in Medicine and Science, 1500-180o, eds. Elaine Y. Leong and Alisha Rankin (Farnham, 2011), 23-46, here 35; Jo Wheeler, Renaissance Secrets: Recipes and Formulas (London, 2009); Elaine Y. Leong and Alisha Rankin, eds., Secrets and Knowledge in Medicine and Science, 1500-1800 (Farnham, 2011), with further reading. On beautifying manuals within this tradition, Snook, "The Beautifying Part," 10-33; Snook, Women, 22-6. 
reaching a level of health that corresponds with physical beauty. ${ }^{65}$ However, he embedded the chapter on cosmetics in the art theoretical framework of his treatise - specifically, in his account on painting techniques. The link Haydocke establishes between art and medicine stems from his professional background as a medical student. It should be viewed against the background of physicians' emerging interest in the fine arts and the birth of the English virtuoso in seventeenth-century culture. ${ }^{66}$

Haydocke's illustrations, such as Table A, which shows the ideal proportions of man and woman, give visual evidence of the fact that the human body was the point at which Haydocke's interests in medicine and art intersected (Fig. 6). Karl Höltgen suggests that, beside Dürer, Haydocke may have also been aware of anatomical plates such as the 1559 edition of Vesalius' anatomical atlas by Thomas Geminus (1510-1562) (Fig. 7). ${ }^{67}$ Ever since Leonardo da Vinci famously demonstrated the importance of drawing as an epistemological tool for understanding the human anatomy, artistic training and the study of the anatomy were linked. ${ }^{68}$ This kind of a professional curiosity may have also motivated Haydocke to learn and practice artistic techniques. In his preface, Haydocke informs readers that he "painfully" practiced painting for seven years before publishing his Tracte of paintinge. ${ }^{69}$

In English culture around 1600, the interests and curiosities of physicians were not limited to anatomy, but comprised empiric knowledge as a whole. Sir Théodore Turquet de Mayerne (1573-1655) (Fig. 8), physician to the kings and queens of England and friend of the court painter Peter Paul Rubens, for instance, demonstrated an empirical curiosity and knowledge of the materia medica in various genres: from the printed pharmacopoeia and manuscripts

65 Gadebusch Bondio, Medizinische Ästhetik, 42-55.

66 The term was first used in 1634 by Henry Peacham, The Compleat Gentleman (Oxford, 1906), 104-5. Walter E. Houghton, "The English Virtuoso in the Seventeenth Century I," Journal of the History of Ideas, 3 (1942), 51-73; and, more recently, with further reading Hanson, English Virtuoso, 2-8.

67 Höltgen, "Haydocke," 21-3. Cf. Hanson, English Virtuoso, 43-7.

68 See, with further reading, Alessandro Nova, "La dolce morte: Die anatomischen Zeichnungen Leonardo da Vincis als Erkenntnismittel und reflektierte Kunstpraxis" Zeitsprünge: Forschungen zur frühen Neuzeit, 9 (2005), 101-30. Alessandro Nova and Domenico Laurenza, eds., Leonardo da Vinci's Anatomical World, (Venice, 2011); Martin Clayton and Ron Philo, eds., Leonardo da Vinci: Anatomist, exhibition catalogue (London, 2012). For anatomy as part of artistic training in the early modern period, see, e.g. Spectacular Bodies: The Art and Science of the Human Body from Leonardo to Now, exhibition catalogue London, ed. Martin Kemp and Marina Wallace (Berkeley, 200o), 69-9o.

69 On Haydocke's artistic work, see Höltgen, “Haydocke.” 


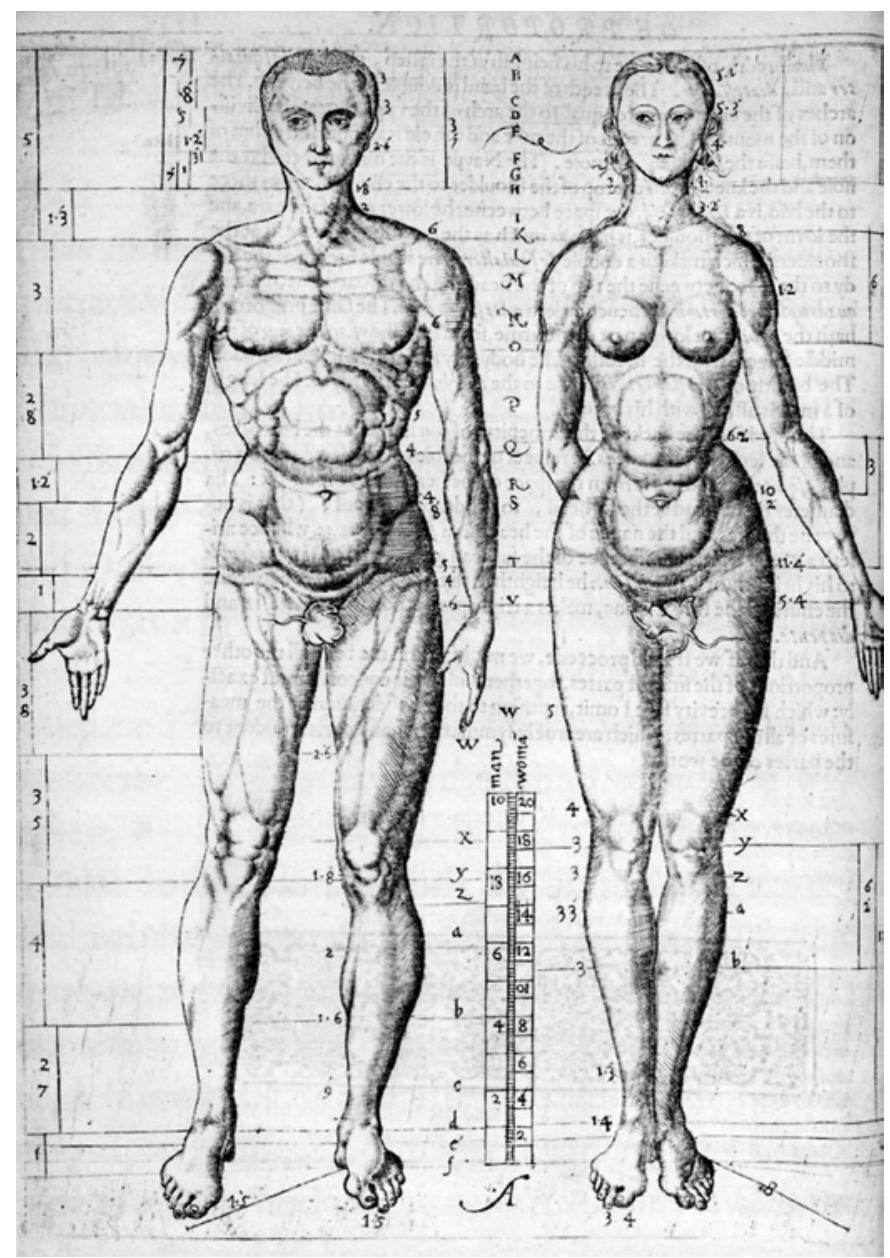

FIGURE 6 Table A in: Richard Haydocke, A tracte containing the artes of curious paintinge (Oxford, 1598). (C) THE HUNTINGTON LIBRARY, SAN MARINO, CALIFORNIA.

with remedy collections for the kings and queens to his famous manuscript on artistic practice and artistic materials. ${ }^{70}$ The preface of Haydocke's Tracte of paintinge situates the link between art and medicine within the university

70 Cf. Hugh R. Trevor-Roper, "Mayerne and his Manuscript," in Art and Patronage in the Caroline Courts, ed. David Howarth (Cambridge, 1993) 264-93; Elizabeth Lane Furdell, The Royal Doctors: Medical Personnel at the Tudor and Stuart Courts (Rochester, 2001), 99-120; Brian Nance, Turquet de Mayerne as Baroque Physician: The Art of Medical Portraiture (Amsterdam, 2001); Hanson, English Virtuoso, 36-9. 


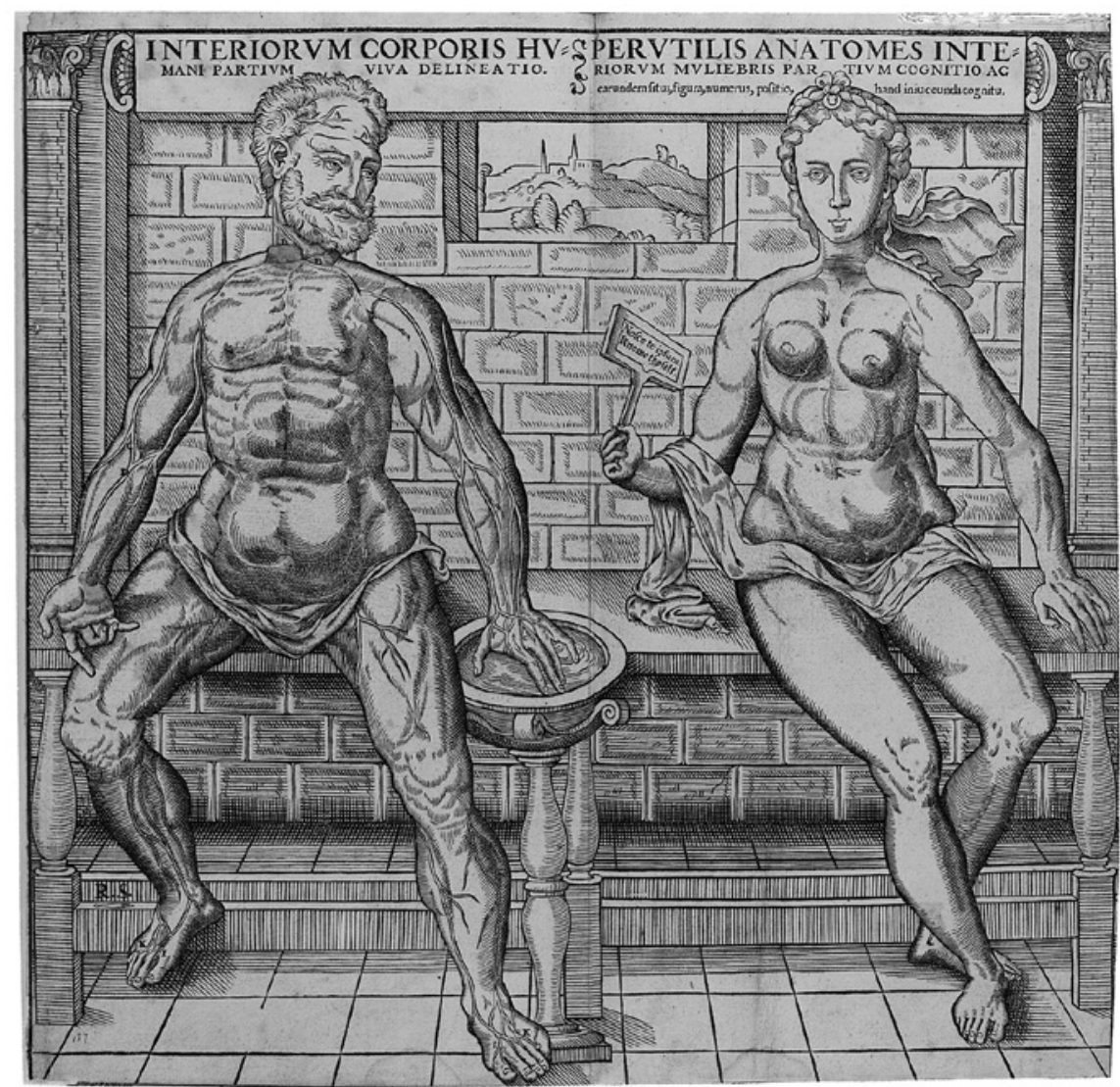

FIGURE 7 Anatomical plate in: Thomas Geminus, Compendiosa Totius Anatomiae Delineatio (London, 1559). (C) WELLCOME LIBRARY, LONDON.

context of Oxford. Thus, the context and motivation of the treatise were not only artistic but also academic. Haydocke dedicated his Tracte to Thomas Bodley (1545-1613), who had started to 'refound' the university library of Oxford in 1598. Haydocke's Tracte became one of the first donations to the Bodleian library. ${ }^{71}$ More importantly, the preface includes a letter to the author from John Case (d. 160o), Aristotelian scholar and teacher of philosophy at Oxford. ${ }^{72}$

$71 \quad$ Höltgen, "Haydocke," 15.

72 John Case, "Iohn Case D. of Physicke to his friende R.H. of New Colledge," in Haydocke, Tracte, n.p. On John Case and his contribution to the peripatetic reception in the English Renaissance, see Charles B. Schmitt, John Case and Aristotelianism in Renaissance England (Kingston, 1983). 


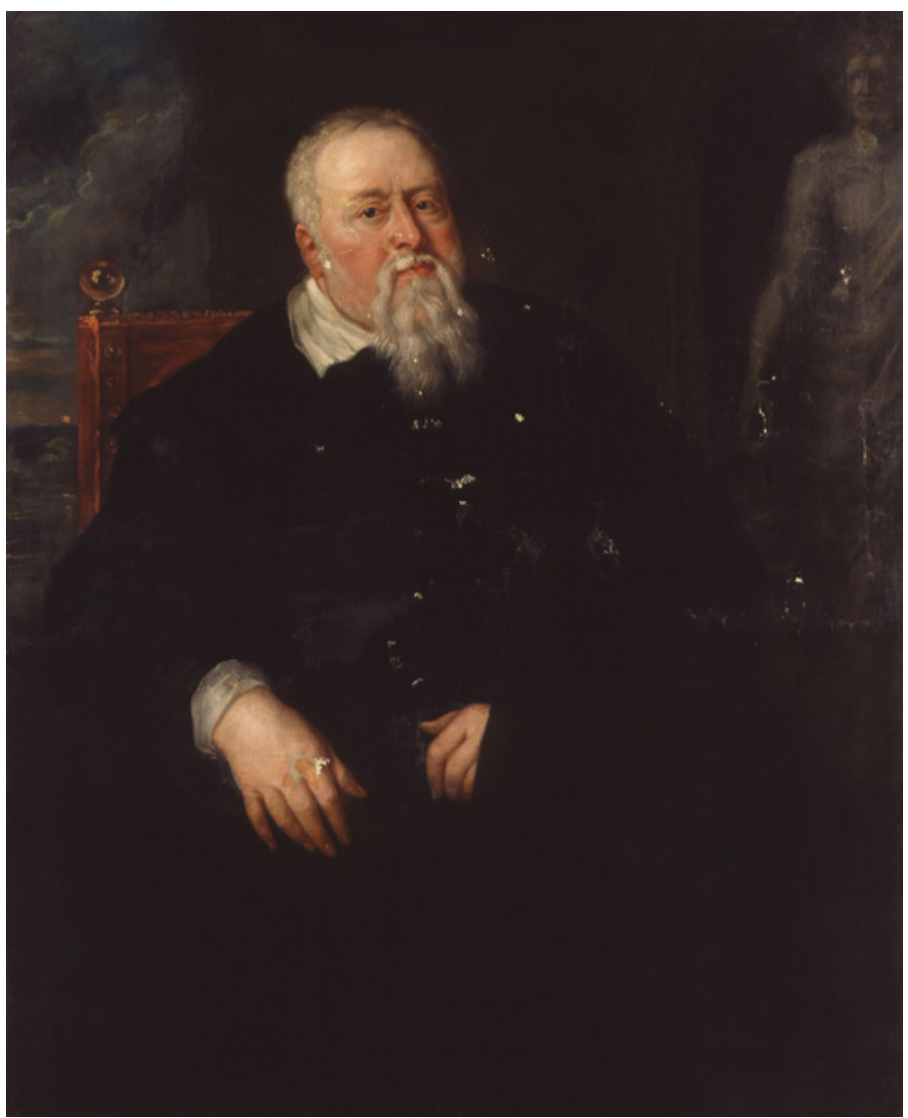

FIgURE 8 Portrait of Sir Théodore Turquet de Mayerne, after Peter Paul Rubens, ca.1630, oil on canvas. (C) NATIONAL PORTRAIT GALLERY, LONDON.

Case praises Haydocke's book for its comprehensive view of various subjects, from anatomy and geometry to pharmacology. Guiding the reader "from Hippocrates to Apelles," these subjects where unified by art as a medium and tool of epistemological knowledge. ${ }^{73}$

Both Haydocke and Case were physicians as well as artistic practitioners. For Case, painting was a liberal art, a useful tool in educating young men and a medium of epistemological recording equal to the writer's pen. ${ }^{74}$ Like Haydocke, Case may have also been involved in the design of the pictorial motifs of

73 Case, "Iohn Case [...] to his friende," n.p.: "If Dioscorides will make an Herball, here he may have skill to set forth hearbes, plantes, and fruits, in most lively colours."

74 John Case, Sphaera Civitatis (Oxford, 1588), viII, 3, 8: "Sub pictoria ergo scientia calamum scribentis, Apellis penicillum, statuam Polycleti, Euclidis lineam, Ptolomaei tabulam 


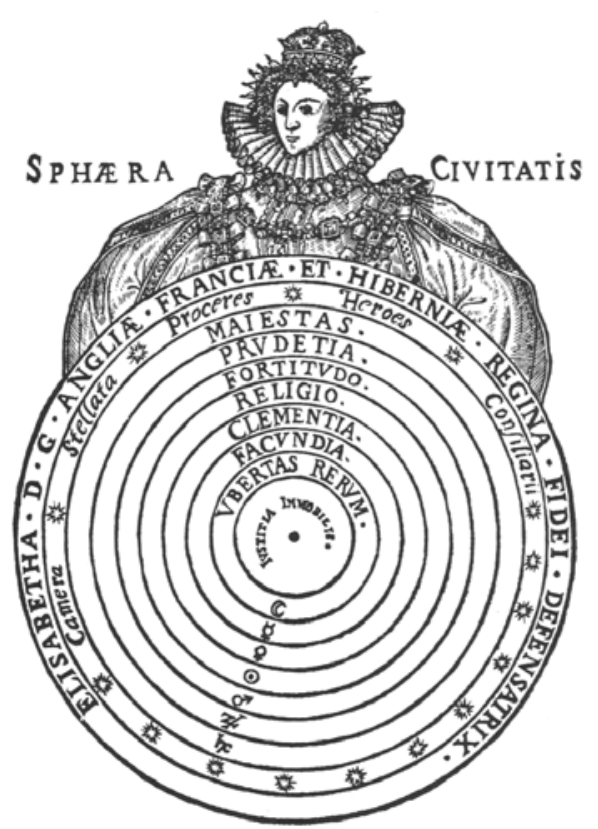

FIGURE 9

Frontispiece in:John Case, Sphaera Civitatis (Oxford, 1588). (C) BAYERISCHE STAATSBIBLIOTHEK, MUNICH.

his books, such as the portrait of Queen Elizabeth in the frontispiece of his commentary of Aristotle's Politics entitled Sphaera civitatis (1588) (Fig. 9).

This emphasis on the status of painting as a liberal art, however, was not limited to the scholars in Haydocke's circle. In his treatise Arte of Limning, the painter Nicholas Hilliard declares limning to be "a kind of gentill painting." 75 John Pope-Hennessy notes that the "gentility of painting" claimed by Hilliard, Case and Haydocke derives from Baldassare Castiglione's bestseller, The Book of the Courtier (1528), and Thomas Hoby's English translation (1561). In it, Castiglione declares painting suitable for the education of young gentlemen and also ennobled the social rank of painters. ${ }^{76}$ In England around 160o, social status was as much a concern for painters, such as Hilliard, as it was for physi-

mundique descriptionem comprehendimus." See Belsey, "Icons of Divinity: Portraits of Elizabeth I," 22-31.

75 Quoted after Pope-Hennessy, "Nicholas Hilliard," 91.

76 Ibid. On the reception of Castiglione's bestseller in sixteenth-century England and Hoby's translation, see Peter Burke, The Fortunes of the Courtier: The European Reception of Castiglione's Cortegiano (Cambridge, 1995); and with further references, Riehl, Face of Queenship, 42-4; Christiane Hille, Visions of the Courtly Body: The Patronage of George Villiers, First Duke of Buckingham, and the Triumph of Painting at the Stuart Court (Berlin, 2012), $140-2$. 
cians, such as Haydocke. ${ }^{77}$ Craig A. Hanson stresses that the accomplishments in the arts of physicians like Haydocke and Mayerne, but also the archeological efforts of the physician William Harvey at the court of Lord Arundel, were part of a wider process of socially distinguishing physicians from charlatans, and of artists from artisans. The cultivation of the arts was thus part of their professionalization. ${ }^{78}$ Hanson argues that physicians' particular interest in the arts represents the meaning of the term virtuoso in the first half of the seventeenth century: men of natural philosophy who ennoble their profession through artistic accomplishments. ${ }^{79}$ Only in the second half of the seventeenth century did the interests of curious, accomplished gentlemen turn to natural philosophy and the natural "sciences." 80

To conclude, Haydocke provided the theoretical framework for England's painters and first virtuosi by aiming to "increase of the knowledge of the Arte," as he felt it "never attained to any great perfection amongst us," as he admits in the preface of his Tracte of paintinge. ${ }^{81}$ The independent chapters on the "Book on Colours" supported this framework in a practical way by naming painting techniques and, more importantly, by defining painting implicitly as a technique of coloration. ${ }^{82}$ In this context, face-painting, like oil painting and limning, was considered an artistic technique that required training and knowledge of both techniques and materials. However, the material knowledge of cosmetic ingredients was of special concern to the physician Haydocke. As a medical practitioner, he promoted a 'natural' ideal of a pleasing complexion that resulted from an overall healthy and balanced physiological constitution by advising against common cosmetic ingredients.

77 See Karin Leonhard on Mayerne's interests in the chemistry of art and pigments in this volume.

78 Hanson, English Virtuoso, 53 .

79 Italy provided examples not only for art and art theory but also for the physician's interest in the arts. Italian Physicians like Paolo Givio and Giulio Mancini collected and wrote about art. Hanson notes that Italian cities such as Padua and Florence were already established locations for the education of English physicians at that time. Thomas Linacre, the first president of the Royal College of Physicians, for instance, learned Greek in Florence and earned his degrees in Padua in 1496. Hanson, English Virtuoso, 52-3.

80 Hanson, English Virtuoso, 53. For the latter type of virtuosi more interested in natural philosophy and "science," also in the context of the Royal Society, see Eamon, Science, $302-5$.

81 Haydocke, Tracte, preface, 104.

82 Ibid., III, $125-6$. 


\section{Cosmetic Ingredients}

Among the most widespread cosmetic ingredients from the early modern period up to the eighteenth century was white lead (ceruse) ${ }^{83}$ Although white lead was poisonous and caused many of the effects associated with lead poisoning - and despite the fact that less harmful powders, such as starch, alabaster and crushed mother-of-pearl, were obtainable - it was popular because it was easy to apply, it was opaque and it created the effect of a smooth complexion. ${ }^{84}$ White lead was both used as a face powder and mixed with colors in the form of paint. Therefore, it could be added to red paint for cheeks and lips (on both canvas and the human face) and mixed with dyes containing precious substances, such as cochineal, henna, ochre, madder and sandalwood. ${ }^{85}$

The chapter on "How to beautifie a white and pallid complexion" in Artificiall embellishments, for example, included a red paint recipe that could be made from sandalwood or vermilion:

[...] use Pomatum and Vermilion made of cinnaberis. Or, Take red Saunders' bruise and steep it for 3 dayes in Aqua Vita, then boile it for an hour over a gentle fire adding a little allum and gum arabick, than strein it and bath the parts therewith. Thake rock allum one ounce boile it in a pinte of running water, when it is dissolved take it off from the fire, let it coal, then adde to it Vermilion finely powdred one ounce, boile them againe to a consumption of half, streine the decoction and keep it for your use. ${ }^{86}$

This cosmetic recipe simultaneously included four representative procedures for the preparation of rouge by recommending the extraction of a red hue from either vermilion or the more precious sandalwood and binding it either with gum arabic or alum. ${ }^{87}$ Vermilion was popular as a flesh color for the face as well

83 Made by dissolving lead in vinegar, it was among the most convenient paint materials. On the production of early modern cosmetics, see, in nuce, Lanoë, La poudre, 28-48. For white lead as white pigment, see Harley, Artists' Pigments, $166-72$.

84 Cf. Lanoë, La poudre, 31-2.

85 Ribeiro, Facing Beauty, 85. For rouge, see Lanoë, La poudre, 48-62.

86 Artificiall embellishments, or Arts best directions how to preserve beauty or procure it (Oxford 1665), 40. Christoph Heyl doubts the attribution to Thomas Jeamson in "Deformity's Filthy Fingers: Cosmetics and the Plague in 'Artificial Embellishments, or Arts best Directions how to preserve Beauty or procure it' " (Oxford 1665)," in Didactic Literature in England, 1500-1800, eds. Natasha Glaisyer and Sara Pennell (Burlington, 2003), 137-51; Phillippy, Painting Women, 43-44; Snook, "Beautifying Part," 17. 


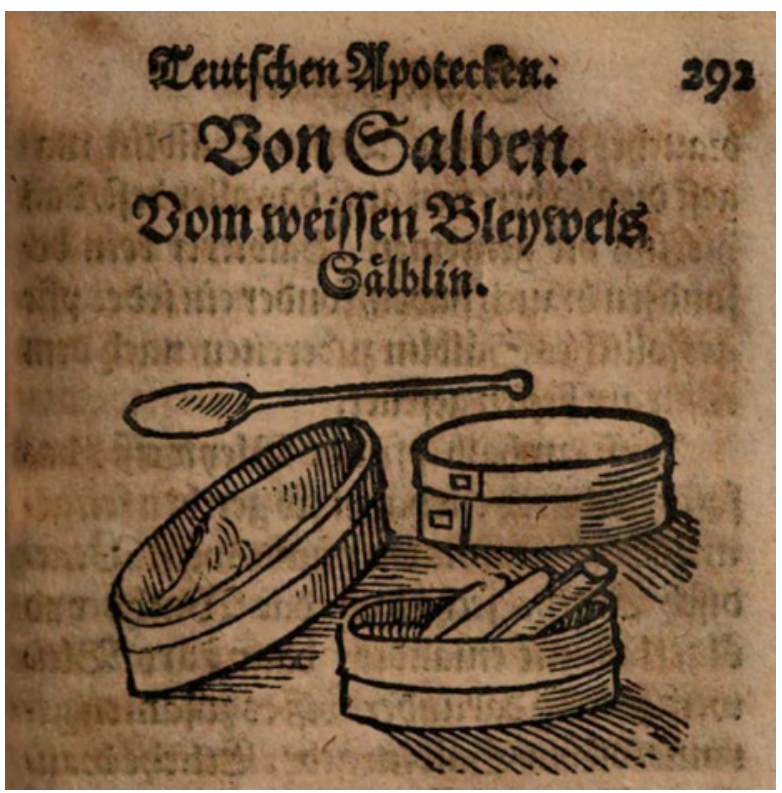

FIGURE 10

Vignette of the chapter on ointments in: Walther Hermann Ryff, Confectbuch unnd Hauß Apoteck (Frankfurt, 1571). (C) BAYERISCHE STAATSBIBLIOTHEK, MUNICH.

as on canvas. In the chapter on coloration in his Schilder-boeck, first published in 1604, the Dutch art writer Karel van Mander (1548-1606), for instance, notes, that the pigment "makes all the flesh parts glow" and gives a warmer hue than crimson. ${ }^{88}$ Lomazzo's consideration of vermilion's effect also applies to both canvas and skin. ${ }^{89}$

Vermilion had been manufactured in Europe since the Middle Ages by melting and subliming mercury and sulfur. By the sixteenth century, it was a moderately-priced commodity retailed by apothecaries. ${ }^{90}$ In his account on

88 Carel van Mander, Het Schilderboek (Utrecht, 1969), 49r: "Carnaty en can niet lijfverwigh bloeyen, maer vermillioen doet al vleeschigher gloeyen." English quote by Filip Vermeylen, "The Colour of Money: Dealing in Pigments in Sixteenth-Century Antwerp," in Trade in Artists' Materials: Markets and Commerce in Europe to 170o, eds. John Kirby, Joanna Cannon, and Susie Nash (London, 2010), 361. See Ann-Sophie Lehmann, "Fleshing Out the Body: The 'Colours of the Naked' in Workshop Practice and Art Theory, 1400-1600," in Body and Embodiment in Netherlandish Art, eds. Ann-Sophie Lehmann and Herman Roodenburg (Zwolle, 2008), 86-109, here 99.

89 Haydocke, Tracte, III, 104. See below for the quote.

9o Assuming that the first was produced from the latter, Artificiall Embellishments, 40, e.g., distinguished between the artificially produced vermilion and the natural, red mineral cinnabar. On production techniques of vermilion, with further references, see, Pamela H. Smith, "Vermilion, Mercury, Blood, and Lizards: Matter and Meaning in Metalworking," in 
cosmetic ingredients, Haydocke does not mention color materials and their embellishing effects - such as vermilion's ability to color skin and canvas red - at all; he only considers metallic cosmetic ingredients, including the far more toxic mercury ("Sublimate"). ${ }^{91}$ Discussing the side effects of quicksilver poisoning on the teeth and the skin, ${ }^{92}$ he also describes production procedures, such as a recipe for a white colored "minerall fucus for the face" from Hugh Platt's Delightes for ladies: ${ }^{93}$

Incorporate with a wooden pestle and in a wooden mortar with great labour foure ounces of sublimate, and one ounce of crude Mercury at least sixe or eight houres (you cannot bestowe too much lavor herein) then with often change of colde water by ablution in a glasse, take awaie the salts from the sublimate, change your water twise every day at the least, and in seaven or eight daies (the more the better) it will bee dulcified, and then it is prepared. Lay it on with the oyle of white poppey. ${ }^{94}$

Platt suggests crushing the mercury and binding it with poppy seed oil, a common pigment binder used in both oil painting and for pharmaceutical purposes. In addition, Haydocke mentions two other methods of binding mercury chloride: one can either prepare a wash for the face with it or use it mixed with a pomatum as a tinted skin ointment.

Despite Haydocke's warnings, Jeamson's and Platt's recipes for skin preparations to beautify the face were based on metallic ingredients, such as white lead, vermilion and mercury. The side effects in Haydocke's treatise notably only applied to women, not men. Edith Snook notes that the majority of

Materials and Expertise in Early Modern Europe: Between Market and Laboratory, eds. Ursula Klein and Emma Spary (Chicago, 2010), 29-49, here 39, which brings together material knowledge, manufacturing practice, and metallic theory.

91 Haydocke, Tracte, III, 130.

92 Ibid.: "Of sublimate, and the bad effects thereof. Diverse women use Sublimate diver[se] ly prepared for increase of their beauty. Some bray it with quicksilver in a marble morter, with a wooden pestle; and this they call argentatum. Others boile it in water, \& therwith wash their face. Some grinde it with Pomatum [...]."

93 The "nature of Sublimate" causes the skin to age prematurely, "black teeth, standing far out of their gums like a Spanish mule; an offensive breath, with a face halfe scorched, and an uncleane complexion." Similarly, Haydocke describes the faces of women who use white lead as quickly becoming "whitered and gray headed, because this doth so mightely drie up the naturall moysture of their flesh." Haydocke, Tracte, III, 130.

94 Hugh Platt, Delightes for Ladies (London, 160o), n. 14: "Sweete Powders, oyntments, beauties, etc." 
sixteenth- and seventeenth-century cosmetic recipe collections were gender neutral. ${ }^{95}$ The chapter on ointments in the German recipe book Confectbuch unnd Hauß Apoteck, written by the pharmacist and writer Walther Hermann Ryff (ca. 1500-1548), for example, begins with a description of the medical benefits of white lead (Fig. 10):

Of all the ointments, the one made of white lead ointment is the most common / for it cools all the hot swellings and inflammations [of the body] when one is afflicted through hitting, falling, striking, / and the like / it drives back the materials flowing hereto / preventing future swelling and inflammation. ${ }^{96}$

In spite of its harmful side effects, white lead was used as a humor-drying antiinflammatory due to its healing and adorning qualities (cooling and drying). ${ }^{97}$ White lead and mercury had an important place in early modern medical and alchemical practice. Edith Snook, however, concludes that the important categories in distinguishing recommended materials from dangerous ones were gender divergences in the production and use of cosmetics, not the effects of the ingredients themselves: ${ }^{98}$

The use of chemical ingredients alongside herbal ones in the practice of beautifying physic illustrates a form of experimental and intellectual authority and a challenge to attempts by scientists and physicians to delineate exclusionary, gendered categories of knowledge. ${ }^{99}$

Likewise, the young physician Haydocke, in his catalog of harmful cosmetics ingredients, admits the therapeutic value of substances such as mercury and white lead but warns against their use by women. ${ }^{100}$

95 Snook, "Beautifying Part," 13.

96 Walther Hermann Ryff, Confectbuch unnd Hauß Apoteck (Frankfurt a. M., 1571), 292: "Under allen Sälblin ist das weiß Bleiweiß Sälblin garnahe dz gebreuchlichst / dann es fület alle hitzige geschwulst und entzündung / so mann sich verwarloset hat mit stossen / fallen / schlahen / und dergleichen / so treibet es die herzü fliessend Materi widerumb zu rück / wehzet künfftiger geschwulst vnnd entzündung." See, Eamon, Science, 69-102. Cf. Nicholas Culpeper, A physicall directory, or, A translation of the London dispensatory (London, 1649), 74 .

98 Snook, "Beautifying Part," 14.

99 Ibid., 24.

100 Haydocke, Tracte, III, 130. Snook, "Beautifying Part," 23. 
Cosmetic ingredients and medicinal remedies, in sum, overlapped with painting colorants and oscillated between healing and harming, portraying and disguising, adorning and disfiguring. The case of white lead very much demonstrates that these connotations were determined by the proportion and composition of the pharmaceutical substances, their preparation, and the gender of the people involved in the production process: as a face-paint, it corrupted female integrity both morally and physically; as a pharmaceutical substance, it was a recommended remedy in medical practice.

\section{Beautifying Materials - Colors of Beauty}

Merging the fields of medicine, cosmetics, and painting, the colors of beauty intersect in early modern writings on art and beauty at the convergence point of the human body and in the work of its male practitioners: in this context, physicians and painters. Different color worlds thus meet at the junction of the human body. Practitioners of art and medicine, of painting, physiology, anatomy and pharmacology shared a common interest in observing, examining and describing the human complexion and its colors as a medium of epistemology as well as of professional training and distinction. As discussed above, Firenzuola's Dialogo delle bellezze delle donne described the colors of the complexion and lips as being visual signs of the body's physiological qualities. Resulting from a good balance of the four fluids of the body, hues of red, candido (fair), white, vermillion and incarnato (flesh-pink) were thought to correspond with a healthy constitution. Regarding Haydocke's account of cosmetic substances, these colors of beauty could be generated by substances that, rather than covering the 'natural' complexion, altered its color to conform to desirable hues of beauty ranging from white to red. Although Haydocke distinguishes between "apparent" and "real" colors, in keeping with the Peripatetic tradition, he does not apply this in his discussion of cosmetics colors: "Vermilion and lake make the colour of ripe strawburies, roses, redlippes, rubies, bloud and skarlet; the same mixtures with white, make the colour of red cheekes, of faire carnation and damaske roses." ${ }^{101}$ Combining color pigments, pigment mixtures, and color hues, such as the color of strawberries, roses and rubies, he brings together the chromatic bodies of nature, the red pigments of art and medicine, and mixes them with white and red - the apparent colors of beauty.

101 Haydocke, Tracte, III, 104. 